\title{
COMPARISON OF AGE ESTIMATES FROM VARIOUS HARD PARTS FOR REDFIN PERCH, Percafluviatilis, IN TASMANIA
}

\author{
Irwan Jatmiko'), James Haddy2) and Mike Williams²) \\ 1) Research Institute for Tuna Fisheries Benoa-Bali \\ 2) Australian Maritime College, University of Tasmania-Australia \\ Received January 08-2013; Received in revised form May 01-2013; Accepted June04-2013 \\ Email: irwan.jatmiko@gmail.com
}

\begin{abstract}
Whole otoliths, sectioned otoliths, scales and vertebrae were used to select the most suitable for age determination of redfin perch, Percafluviatilis. Redfin perch were sampled from Trevallyn Lake and Brushy Lagoon using fyke nets, gillnets, electrofishing and rod and line angling. Age estimates were assessed for comparison between readings and among structures. One-way ANOVA of readability scores highlighted that sectioned otolith was the most obvious compare to other hard parts. Sectioned otoliths also showed the highest (93.9\%) agreement between readings, followed by vertebrae (68.7), scales (38.8) and whole otoliths (29.9). Furthermore, there were no significantly different $(p>0.05)$ between first and second readings from sectioned otolith and vertebrae but significantly different $(p<$ $0.05)$ to those from scales and whole otoliths. When sectioned otoliths' ages were compared with other structures, vertebrae showed the highest (47.6\%) agreement to those followed by scales $(25.2 \%)$ and whole otoliths (20.4\%). Age estimates from sectioned otoliths were significantly different $(p<$ $0.05)$ to the values obtained from vertebrae, scales and whole otoliths. This finding demonstrated that sectioned otoliths are the best hard part for age determination for redfin perch in Tasmania.
\end{abstract}

KEYWORDS: Hard parts, one-way ANOVA, age determination

\section{INTRODUCTION}

Redfin perch are also known as reddies, European perch, English perch or Eurasian perch (Allen et al., 2002). They were first introduced to Tasmania between 1858 and 1862 and to Victoria in the 1861, now distributed and considered a pest species throughout all southern Australian states, including Tasmania (Morgan et al., 2002; McAllister, 2007; Rowe et al., 2008). Despite their pest species status, they can be an excellent sport fish because of their fighting and good eating qualities (Allen et al., 2002; DPI-NSW, 2011). Moreover, they are capable of growing to 60 $\mathrm{cm}$ in length and $10 \mathrm{~kg}$ in weight, but generally in Australia, fish only reach around $40-45 \mathrm{~cm}$ in length and $1-2 \mathrm{~kg}$ in weight (Water Watch, 2011). Although some individuals are capable of reaching these sizes, the majority mature early with populations becoming dominated by large numbers of stunted individuals of little recreational benefit (McAllister, 2007).

Large redfin perch are a significant predator species of other fish species and are suspected to be one of the causes of reduced the numbers of recreational trout fisheries (Morgan et al., 2002; Rowe et al., 2008). As they have also been shown to prey on juvenile trout, the success of trout stocking programs can also be affected. Consequently in redfin infected waters, stocking programs usually release larger yearling trout, which are more expensive to produce than fingerlings, to reduce predation pressures from the redfin population. In addition to being piscivorous when large, they also compete for habitat with native fish and in some cases have even totally displaced the native fish population from the invaded waterways. On mainland Australia, redfin are known to be carriers of the epizootic haematopoietic necrosis virus (EHNV) which causes a significant disease risk to other native and endangered freshwater species (Langdon, 1989; Whittington et al., 1996). As a result redfin in NSW were upgraded to a Class 1 noxious species in December 2010. It means that they are classified as pest species that are dangerous to other fish and aquatic environments (DPI-NSW, 2011). However, within Tasmania, the Inland Fisheries Service (IFS) has declared redfin as an "acclimatised" pest fish, where management efforts are focused on preventing further spreading rather than trying to control numbers of established populations (IFS, 2011).

Age determination of fish using vertebrae is by counting the growth rings. This technique is useful for species which have no otolith like shark (Simpfendorfer, 1993). There is no histological evidence of resorption from shark vertebral in their life history (Clement et al., 1992). Filmalter et al. (2009) recommended that vertebrae are the most suitable hard part for yellowin tuna age determination. However, such as otolith, using vertebrae are causing the death of fish (King, 2010). 
The use of otoliths is very reliable for determining age of fish (Maceina et al., 2007) by counting the annulus (plural, annuli). However, the most harmful of using otolith is always followed by the death of fish (King, 2010).Another way for age determination is using vertebrae by counting the growth rings. This method is preferred for species that have no otolith like shark. Moreover, vertebrae show no evidence of resorption at any time in their life history (Clement et al., 1992). Filmalter et al. (2009) stated that vertebrae are recommended for age determination in yellowfin tuna. However, many elasmobranch species are too poorly calcified to provide on age information (Goldman, 2004). Furthermore, such as otolith, the use of vertebrae also followed the death of fish (King, 2010). The objective of this study is to select the most suitable hard partfor age determination of redfinperch.

\section{MATERIALS AND METHODS}

\section{Sample Collection and Biological Processing}

Redfin perch were sampled from Lake Trevallyn between September 2011 and February 2012 using four different fishing methods (fyke nets, gillnets, electro fishing and rod and line angling). Due to poor capture numbers in Trevallyn Lake, additional fish were sourced from whole frozen samples captured from Brushy Lagoon in April 2009.

\section{Hard Parts Handling, Readability and Age Determinations}

Dried scales were mounted between two glass slides taped together with clear adhesive tape. Whole otoliths were viewed under a Leica MZ 9.5 stereo microscope fitted with a digital camera and photographed. Whole otolith images were analysed using Image $J$ to determine otolith length $( \pm 0.01 \mathrm{~mm})$ and assign an age estimation reading. Once whole otoliths were read, otoliths and vertebrae were embedded in clear resin, transversely sectioned $(600 \mu \mathrm{m})$ using a gemmasta jewellers saw and polished with a 1.200 grit faceting wheel. Polished otolith and vertebrae sections were rinsed and allowed to dry prior to being mounted onto glass slides. Mounted vertebrae and otoliths were subsequently photographed using a Leica MZ 9.5 stereo microscope for later image analysis and age determination using the Image $J$ program. The complete annual increment (band) consists of an opaque and translucent zone. Under reflected light, the opaque zone appears thin bright and the translucent zone appears thicker dark.

The readability of hard parts assessed was assigned from interpretation scores developed by Green and Krusic-Golub, 2002 with a scale from 1 (excellent) to 5 (unreadable). Age determination is by counting the growth rings in each hard part. Each hard part was aged twice to determine the level of consistency.

\section{Comparison of Age Determinations}

Age determinations were compared by calculating the Percent Agreement (PA), Index of Average Percent Error (IAPE) between readings and between sectioned otolith and other hard parts. PA was simply calculating the percent of age agreement between pairs. IAPE was calculating using formula from Beamish \& Fournier (1981):

$$
\mathbf{I A P E}=\frac{1}{R} \sum_{i=1}^{R} \frac{\left|x_{i j}-x_{j}\right|}{x_{j}} \times \mathbf{x} 100
$$

where $x_{i j}$ is the $i$-th age determination of the $j$-th fish, $x_{i}$ is the average age calculated for the $j$-th fish and $R$ is the number of times each fish was aged.

\section{Statistical Analysis}

One-way (Analysis of Variance) ANOVA and Tukey post-hoc test were conducted to determine if readability scores significantly different among four different hard parts.Paired t-test was conducted to determine if determined age significantly different between first and second reading in four different hard parts and between sectioned otolith and other hard parts.

\section{RESULTS}

\section{Sample Description}

A total of 384 redfin perch were examined with fork lengths (FL) ranging from 81 to $404 \mathrm{~mm}$ (Fig. 1). Although there was no differences in external morphology between sexes of the same size, males were typically smaller (range $81-169 \mathrm{~mm}$ ) whereas females attained much larger sizes (range 85 to 404 $\mathrm{mm})$. 


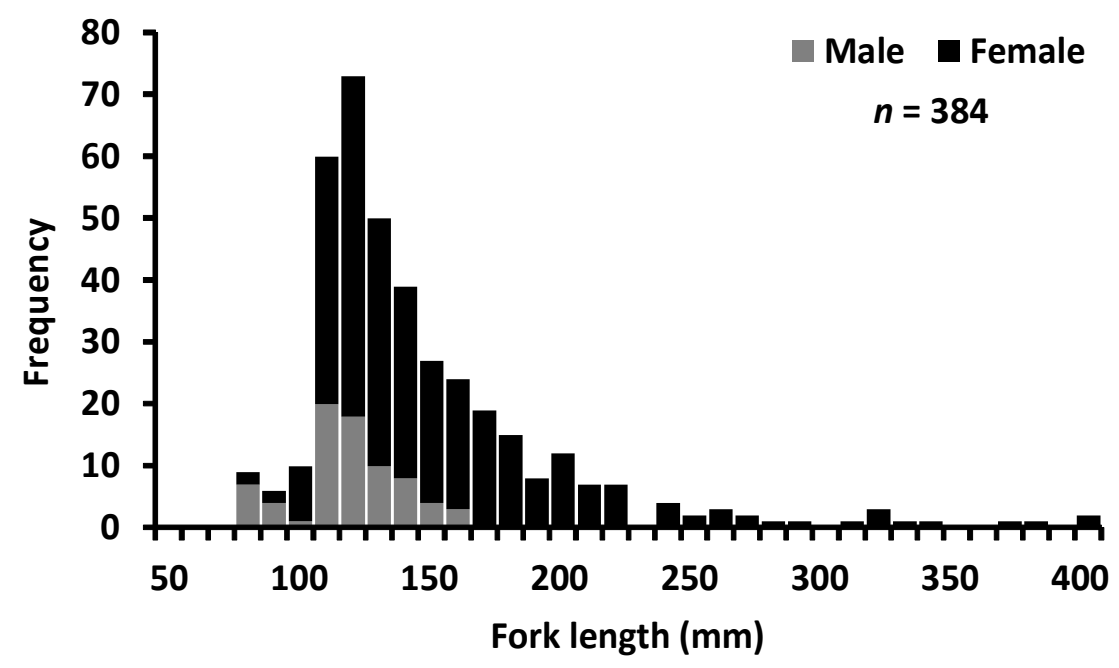

Figure 1. Length frequency for male and female redfin perch (Percafluviatilis).

\section{Readability of Hard Parts}

Four different hard parts of redfin perch were observed to determine the age of redfin perch (Fig. 2). One-way ANOVA analysis of readability scores highlighted that sectioned otolith was the most obvious compare to other hard parts $\left(F_{3,584}=333.924\right.$; $p<0.05)$. Sectioned otolith had the lowest score (1.66) followed by vertebrae (2.69). Conversely, scale and whole otolith had poor appearance with score of 3.69 and 3.82 , respectively. Interpretations of age determination from the same fish (fish no. 369) show that sectioned otolith had only one interpretation (4 years), vertebrae had two interpretations (4 and 5 years) and scale and whole otolith had three interpretations $(3,4$ and 5 years). Furthermore, sectioned otolith had the lowest readability score with score 2 followed by vertebrae with score 3 . In contrast, scale and whole otolith had poor appearance with score 4 each (Fig. 3).

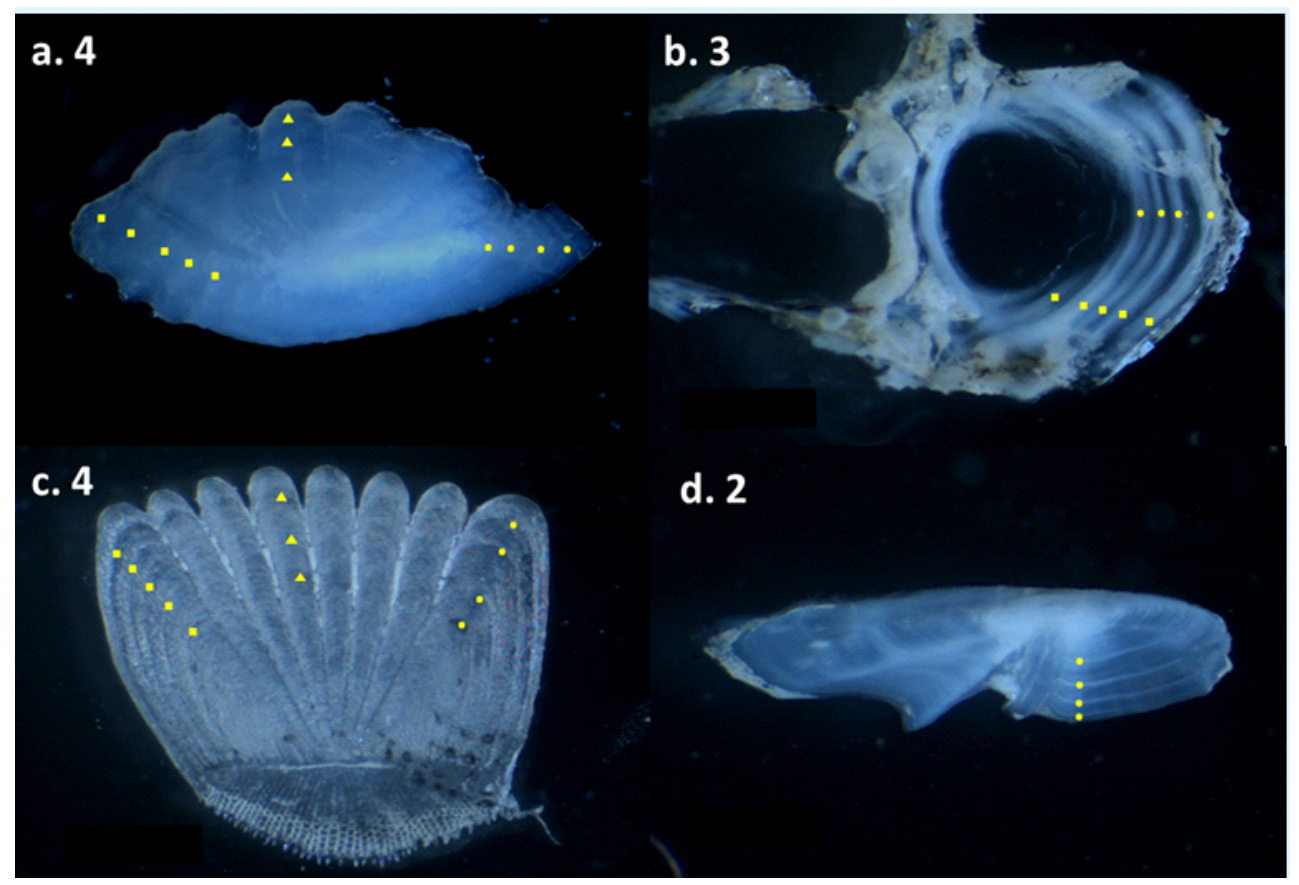

Figure 2. Whole otolith (a), vertebrae (b), scale (c) and sectioned otolith (d) from the same fish. Numbers are the readability scores for each hard part. Circles, squares and triangles are number of increments from first, second and third interpretations respectively. 


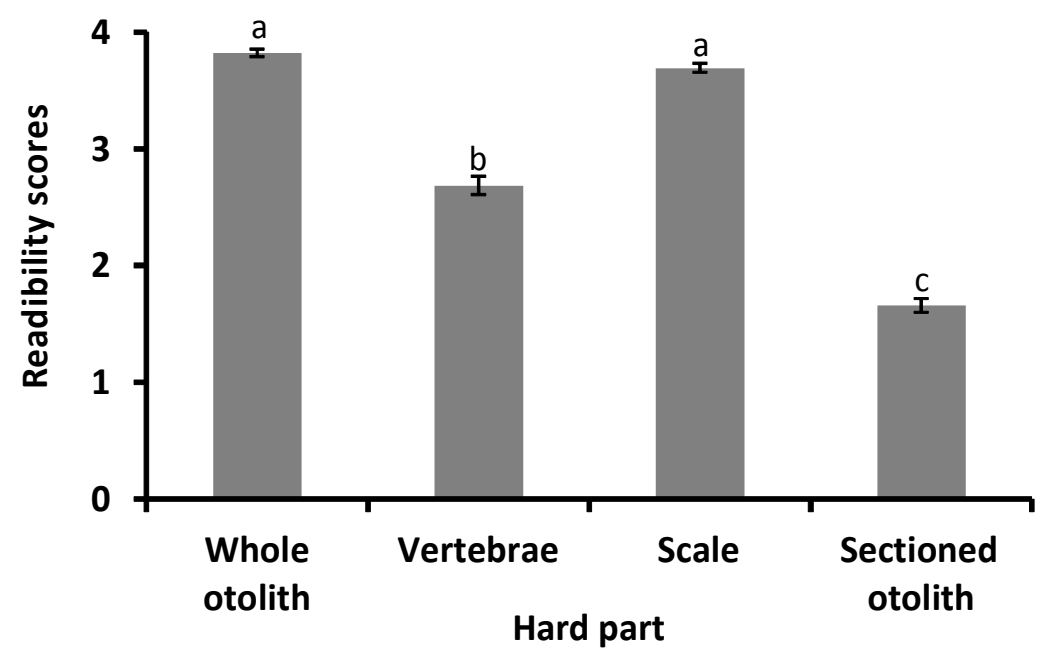

Figure 3. Readability scores from four different hard parts. Values are mean +/- SE. Different letters are significantly different $(p<0.05)$.

\section{Inter Reading Variation Between First and Second Reading}

The similar results were also obtained from the calculation of percent agreement (PA) and index of average percent error (IAPE) (Fig. 4). It showed that sectioned otolith is the best in the precision of the age determinations followed by vertebrae, scale and whole otolith. Sectioned otolith had the highest PA $(93.9 \%)$ and the lowest IAPE with $1.2 \%$. Furthermore, paired t-test showed that sectioned otolith and vertebrae were the best hard parts in the precision of age determination. There were no significant difference between first and second readings in sectioned otolith $(t=-1.677, d f=146, p=0.096)$ and vertebrae $(t=$ $0.499, d f=146, p=0.619)$. In contrast, there were significant differences between first and second readings in scales $(t=-4.036, d f=146, p<0.001)$ and whole otolith $(t=12.668, d f=146, p<0.001)$. For whole otolith, it showed that age was underestimated at 2 years or more, while age from scale was overestimated from 0 to 5 years.

\section{Inter Reading Variation Between Sectioned Otolith And Other Hard Parts}

The comparison of age determination among hard parts showed that there was significant difference between age from sectioned otolith with whole otolith $(t=29.231, d t=146, p<0.001)$, vertebrae $(t=2.101$, $d f=146, p=0.037)$ and scale $(t=-14.792, d f=146$, $p<0.01)$. Vertebrae showed overestimation from 0 to 2 years and underestimation at 3 years or more. Whole otolith and scale showed overestimation from 0 to 4 years and underestimation at 5 years or more respectively (Fig. 5).

\section{Age Structure}

Due to the great accuracy and precision, only sectioned otolith were used in further analysis. Age frequencies were dominated by 1 year redfin perch with around $50 \%$ of samples. When getting older, the frequencies were decreased only $2 \%$ at age 6 years and $1 \%$ respectively at age 7 to 10 years (Fig. $6)$. 

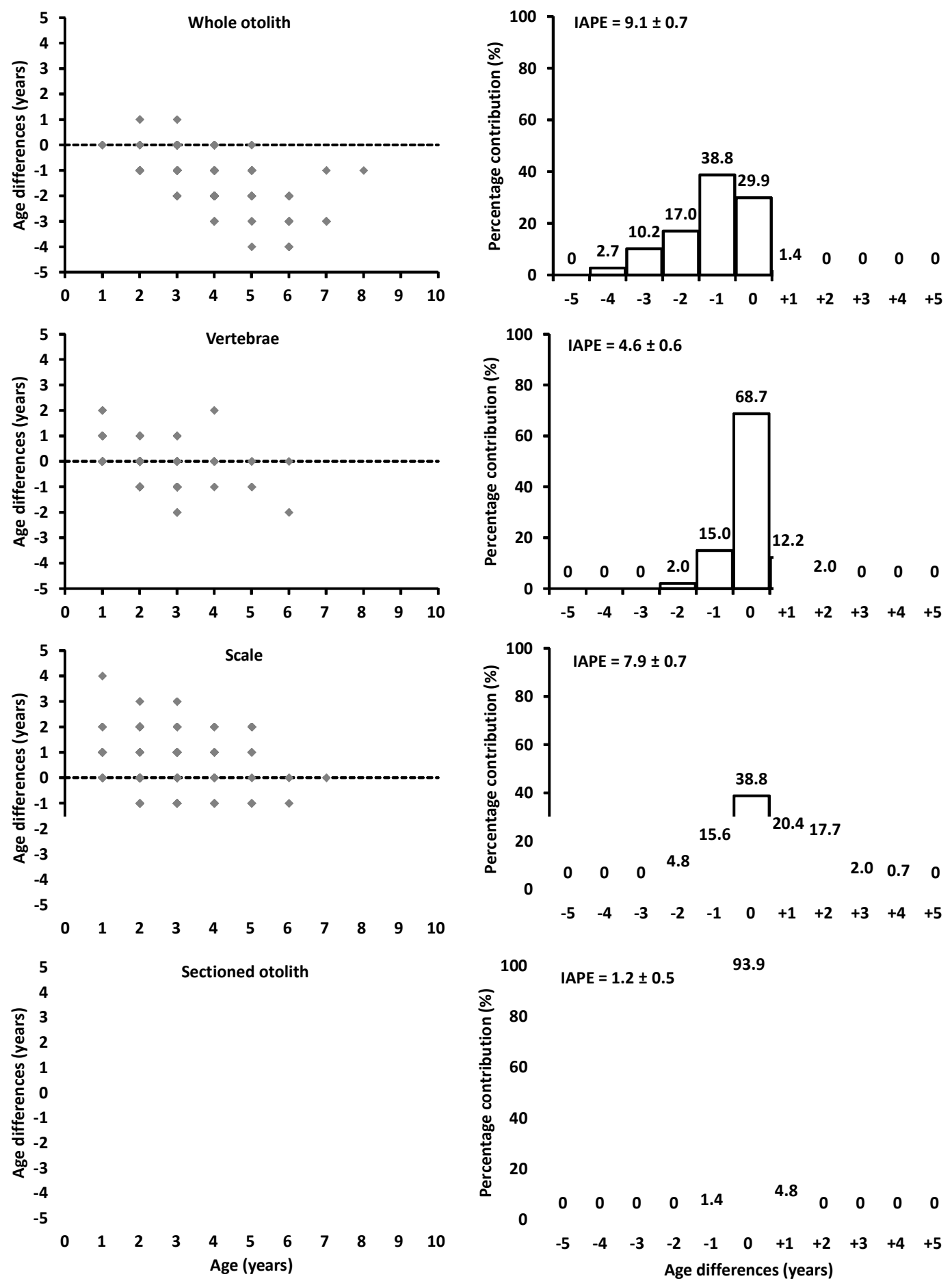

Figure 4. Age differences between first and second reading in four different hard parts. Values of index of average percent error (IAPE) are mean \pm standard error (SE). Dash line is 0 differences. Age differences at 0 are percent agreement (PA). 

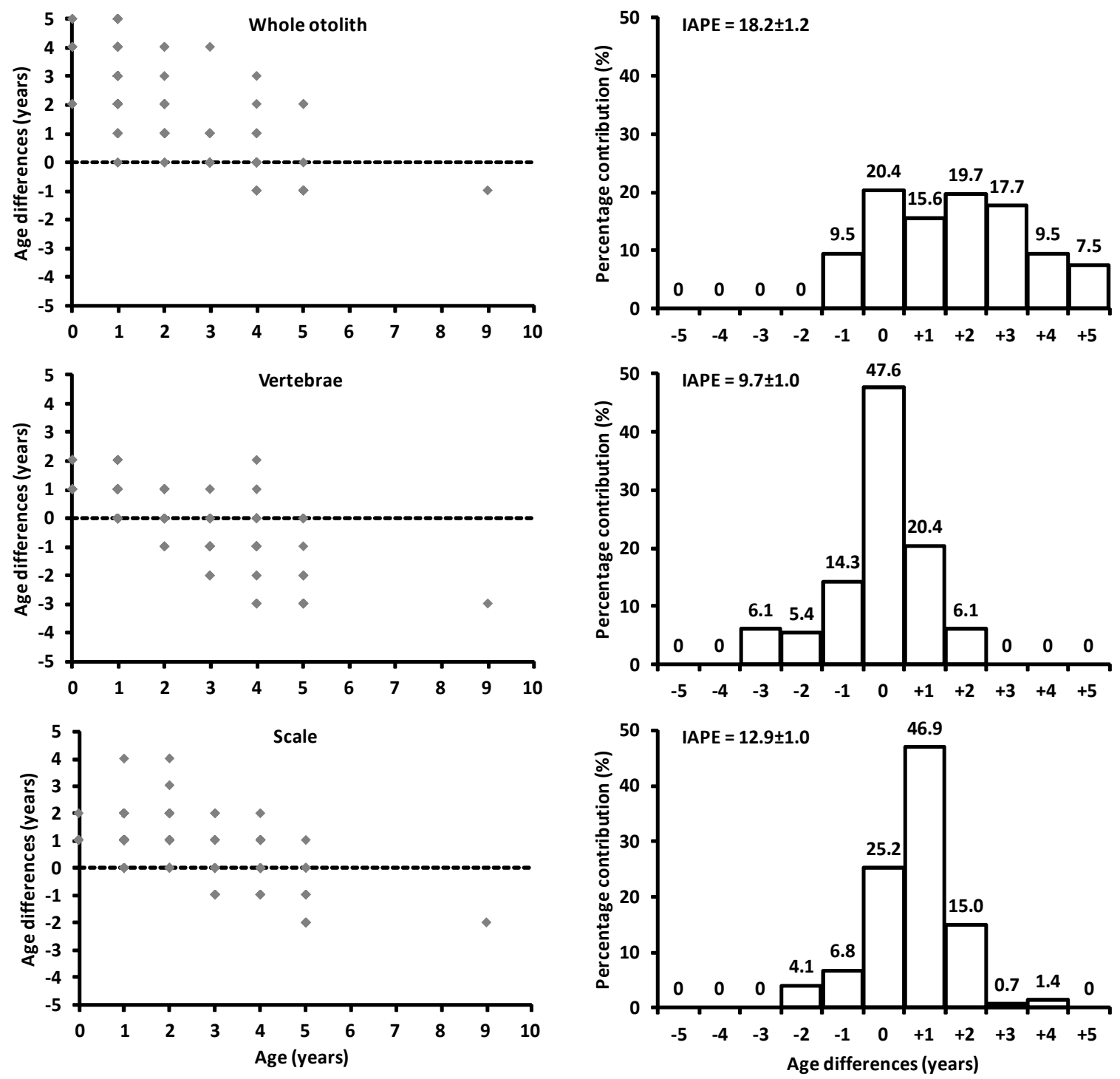

Figure 5. Age differences between sectioned otolith and other hard parts. Values of index of average percent error (IAPE) are mean \pm standard error (SE). Dash line is 0 differences. Age differences at 0 are percent agreement $(\mathrm{PA})$.

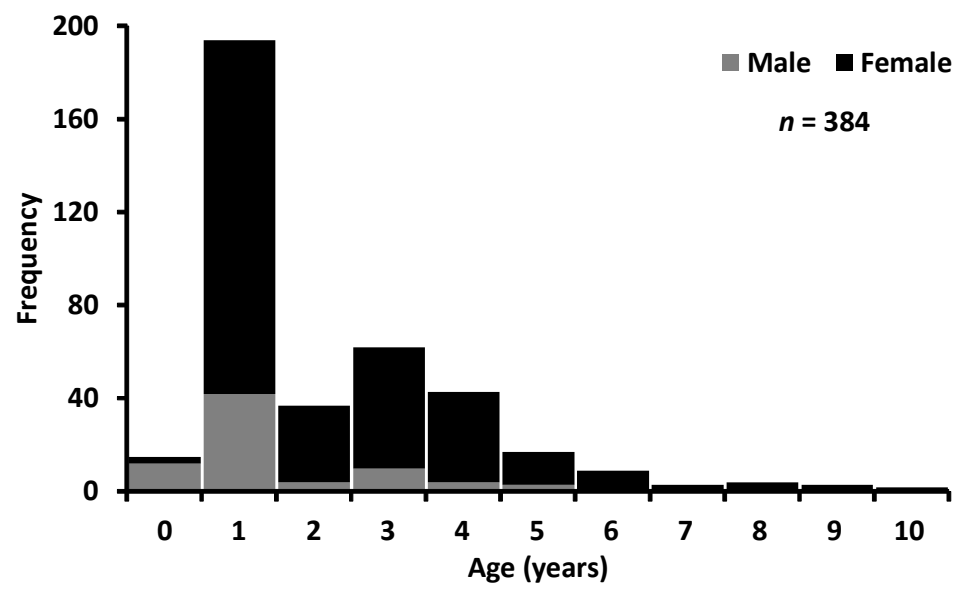

Figure 6. Age frequencies for male and female redfin perch (Percafluviatilis) from sectioned otolith. 


\section{DISCUSSION}

This study is the first published account to compare the readability among hard parts for age determination and back calculation analysis to assess biphasic growth in redfin perch. The results found that redfin perch grow up to 5 and 10 years for males and females, respectively. In another study, McAllister (2007) reported similar age structure in a separate population of redfin perch in Lagoon of Islands, Tasmania. McAllister also discovered that male and female redfin perch reached sexual maturity in their first year and the population became stunted. The redfin population was found to be dominated by $80 \%$ females (sex ratio was 4.1 females: 1 male). Similar results were obtained from previous studies, sex ratio was $3.4-$ 4.6 females: 1 male (McAllister, 2007; Pitman, 2009). In contrast, it is very different from Redfin populations in Western Australia where sex ratio was 1.75 females: 1 male (Morgan et al., 2002). With females dominating, many eggs are produced and it is hypothesised that males do not need to reach larger size to continue their reproductive competitiveness.

In this study, redfin perch attained annual mean fork length at age back calculated of 75, 91, 107 and $127 \mathrm{~mm}$ for males and 78, 117, 146 and 172 for females over four years, respectively. This result is comparable to the length at age data reported by McAllister (2007) of annual mean fork length from observed age of 100 , 111,120 and $127 \mathrm{~mm}$ for males and 101, 144, 183 and $217 \mathrm{~mm}$ for females over four years, respectively.

Amongst all hard parts used in the age determination of redfin perch, sectioned otolith was found to be the most reliable hard part followed by vertebrae, scale, and whole otolith. Annual increments on the sectioned otolith were better defined and easier to read as compared to other hard parts. In many studies, sectioned otolith is the best hard part for age determination because of the highest precision (PA $=$ $93.9 \%$ ) and the lowest ageing error (IAPE $=1.2 \%)$. This result is similar to other studies in many species such as Africansharptooth catfish (Khan et al., 2011), southern bluefin tuna (Gunn et al., 2008), endemic tibetan fish (Ma et al., 2011) and channel catfish (Buckmeier et al., 2002). The suitability of otoliths for age estimation is also supported by the fact that otoliths do not show reabsorption and their growth is acellular rather than by calcification (Secor et al., 1995).

\section{CONCLUSIONS}

The objectives of this study were to select the most suitable hard part for age determination of redfin perch in Tasmania. The results of this study indicate that sectioned otolith is the most suitable hard part for age determination of redfin perch. However, other hard parts did show annual growth increments but were not suitable for age determination due to their low accuracy and precision.

\section{ACKNOWLEDGEMENTS}

The authors wish to thank Rob Keeley (Inland Fisheries Service) and Shaun Finlayson (Highland Pacific Exports) for taking time off to help and redfin donations during this project. We also would like to thanks Jon Schrepfer for the help within lab analysis.

\section{REFERENCES}

Allen, G.R., S.H. Midgley \& M. Allen. 2002. Field guide to the Freshwater Fishes of Australia. CSIRO, Victoria, Australia.

Beamish R.J. \& D.A. Fournier. 1981. A Method for Comparing the Precision of a Set of Age Determinations. Canadian Journal of Fisheries and Aquatic Sciences 38, 982-983.

Buckmeier, D. L., E.R. Irwin, R.K. Betsill \& J.A. Prentice. 2002. Validity of Otoliths and Pectoral Spines for Estimating Ages of Channel Catfish. North American Journal of Fisheries Management 22, 934-942.

Clement, J.G., R.A. Officer, \& E. Dykes. 1992. Threedimensional Reconstruction of Shark Vertebrae: A Technique with Applications to Age and Growth Studies. Australian Journal of Marine and Freshwater Research 43, 923-933.

DPI-NSW. 2011. Redfin perch (Perca fluviatilis). Department of Primary Industries, New South Wales, viewed 12 July 2011, [http:// www.dpi.nsw.gov.au/fisheries/pests-diseases/ freshwater-pests/species/redfin-perch].

Filmalter, J.D., O.L.F. Weyl \& W. Sauer. 2009. Otoliths and vertebrae as potential hard structures for ageing South African yellowfin tuna Thunnus albacares. African Journal of Marine Science 31, 271-276.

Goldman, K.J. 2004. Age and growth of elasmobranch fishes. In: J. A. Musick and R. Bonfil (eds). Management techniques for elasmobranch fisheries 76-102 $\mathrm{p}$.

Green, C. \& K. Krusic-Golub. 2002. Age estimates of two species of threadfin bream (Nemipterus 
theodorei and N. aurifilum). Final Report to the Queensland Department of Primary Industries. Marine and Freshwater Resources Institute, Victoria. $12 \mathrm{p}$.

Gunn, J.S., N.P. Clear,T.I. Carter, A.J.Rees, C.A. Stanley, J.H. Farley \& J.M.Kalish. 2008. Age and growth in southern bluefin tuna, Thunnus maccoyii (Castelnau): Direct estimation from otoliths, scales and vertebrae. Fisheries Research 92, 207-220.

Inland Fisheries Service. 2011. Fact Sheet for redfin perch. Inland Fisheries Service, Tasmania, viewed 14 July 2011, [http://www.ifs.tas.gov.au/ifs/ IFSDatabaseManager/SpeciesDatabase/redfin].

Khan, S., M.A. Khan \& K. Miyan. 2011. Comparison of age estimates from otoliths, vertebrae, and pectoral spines in African sharptooth catfish, Clarias gariepinus (Burchell). Estonian Journal of Ecology 60, 183-193.

King, M. 2010. Fisheries biology, assessment and management, $2^{\text {nd }}$ edition. Blackwell Publishing Ltd, Oxford, United Kingdom.

Langdon, J. S. 1989. Experimental transmission and pathogenicity of epizootic hematopoietic necrosis virus (EHNV) in redfin perch, Perca fluviatilis L., and 11 other teleosts. Journal of Fish Diseases $12,295-310$.

Ma, B., C.Xie, B. Huo,X. Yang\& P. Li.2011. Age validation, and comparison of otolith, vertebra and opercular bone for estimating age of Schizothorax o'connori in the YarlungTsangpo River, Tibet. Environmental Biology of Fishes 90, 159-169.

Maceina, M.J., J. Boxrucker, D.L. Buckmeier, R.S. Gangl, D.O.Lucchesi, D. Alsermann, J.R. Jackson \& P.J. Martinez. 2007. Current status and review of freshwater fish aging procedures used by state and provincial fisheries agencies with recommendations for future directions. Fisheries. 32, 329-340.

McAllister, J.D. 2007. An investigation into the population dynamics and trophic roles of redfin perch (Perca fluviatilis) in Lagoon of Islands. Honours Thesis, Australian Maritime College, Tasmania. $11 \mathrm{p}$.

Morgan, D.L., S.J.Hambleton, H.S. Gill\&S.J.Beatty. 2002. Distribution, biology and likely impacts of the introduced redfin perch (Perca fluviatilis) (Percidae) in Western Australia. Marine and Freshwater Research 53, 1211-1221.

Pitman, L.R. 2009. 'Population dynamics of redfin perch, Perca fluviatilis, in Brushy Lagoon, Tasmania'. National Centre for Marine Conservation and Resource Sustainability. Australian Maritime College, Tasmania.

Rowe, D.K., A. Moore,A. Giorgetti,C.Maclean, P. Grace,S. Wadhwa\&J. Cooke. 2008. Review of the impacts of gambusia, redfin perch, tench, roach, yellowfin goby and streaked goby in Australia. Prepared for the Australian Government Departmentof the Environment, Water, Heritage and the Arts. Australia.

Secor, D.H., T.M. Trice \&H.T. Hornick. 1995. Validation of otolith-based ageing andcomparison of otolith and scale-based ageing in mark-recaptured Chesapeake Bay stripedbass, Morone saxatilis. Fishery Bulletin 93, 186-190.

Simpfendorfer, C. A. 1993. Age and growth of the Australian sharpnose shark, Rhizoprionodon taylori, from north Queensland, Australia. Environmental Biology of Fishes 36, 233-241.

Water Watch. 2011. Redfin perch (Perca fluviatilis). Water Watch, North Central, Victoria, viewed 12 July 2011, [http://www.vic.waterwatch.org.au/file/ inform/Redfin.pdf].

Whittington, R.J., C. Kearns,A.D. Hyatt, S. Hengstberger\&T. Rutzou. 1996. Spread of epizootic haematopoietic necrosis virus (EHNV) in redfin perch (Perca fluviatilis) in southern Australia. Australian Veterinary Journal73, 112-114. 